\title{
Construction of Social Reality in Fiction and Phenomenology of Everyday Life
}

\author{
S.V. Rudanovskaya \\ RUDN University \\ Miklukho-Maklaya Str., 6 Moscow, Russian Federation, 117198
}

\begin{abstract}
The idea of the constructed character of social reality implies human contribution to institutional arrangements and cultural patterns that determine the shape of collective existence. The article examines the specific features of social construction seen and studied in phenomenological approach by A. Schutz, P. Berger, Th. Luckmann. The concept reveals significance of daily cognitive style which enables people to structure and understand the world they share with others, escaping situations fraught with gaps of meanings and anomy. The author of the article analyzes the process of social construction, distinguishing it from imaginary building of reality that goes beyond the existed order. Reality of daily life is compared with fictional society represented in J.L. Borges' "Lottery in Babylon". Telling about the social construction as it may be, the story demonstrates the similarities between the mental procedures that underlie real and antiutopian (inhuman) routines. The article also centers on peculiarities of phenomenological beholder's attitude towards sociality. On the one hand, it tends to be free from any theoretical abstractions, imaginary constructions or critical destruction of reality, on the other - inclines to transcend the reified forms of social being and engenders a certain critical message.
\end{abstract}

Key words: social phenomenology, social construction, reification, social actor, existential experience, social imagination, phenomenological beholder, "Lottery in Babylon"

\section{Article history:}

The article was submitted on 30.05.2019

The article was accepted on 08.07.2019

For citation: Rudanovskaya S.V. Construction of social reality in fiction and phenomenology of everyday life. RUDN Journal of Philosophy. 2019; 23 (4):521—532. doi: 10.22363/2313-23022019-23-4-521-532

\section{Introduction: Construction and social imagination}

Constructing means elaborating artifacts well adapted to certain physical and social environment. Primarily it is a rational activity supposed to prevent problems and lead to manageable, predictable and desired results. Engineers, architectures, artists, politicians, gardeners, designers etc. engage in producing different kinds of constructed phenomena, distinguished from natural objects or side effects of human actions. Con-

(C) Rudanovskaya S.V., 2019.

(c) (1) This work is licensed under a Creative Commons Attribution 4.0 International License https://creativecommons.org/licenses/by/4.0/ 
struction implies deliberate and analytical thought, taking into account possible challenges and incidents that may interfere into initial plan and order.

The constructed character of sociality is not evident when the "natural artificiality" (H. Plessner) of familiar environment and patterns of behaviour are taken for granted. But it comes to the fore when the usual environment is seen as the product of human activities, open for social criticism and improvement. To see the constructed character of society is to suggest that it might be different [1. P. 5], and if so, it is possible to imagine the other forms of social being, dependent on human reason and ideas of justice.

One of the influential forms of this imagination is immaculate pictures of cooperative being, created within utopian genre that comes from Plato and Th. More. Introducing other principles of social, economic and political life into narrative, an author of literary utopia is the only "censor" and authority that does not let undesirable or destroying trends into fictional order. The peculiarities of the genre enable its creators to transcend existing constraints of historical situation while depicting a society, congruous with the ideals and manifoldness of real life.

Utopia differs from real societies not by its exotic forms, but by the absolute power of reason and justice over any aspects of social practice. That is a "transparent society", where everything is clear, understandable and can be expressed in dialogue between prudent actors. Actually utopian space is constructed in fictional conversation either between utopians and their guests, or between the travelers to utopian world and their supposed audience. In both cases an imaginary society exists in a narrative within a point of view of benevolent beholder who cares about human needs as well as about perfect order that guarantees human welfare and freedom from oppression.

Guiding collective action, utopian images engender revolutionary movements (from millenarism to student revolts of the sixties) which do partake in constructing societies by challenging the traditional norms [2]. However the social philosophers of the XX century warned against the passion for this kind of social imagination and action accompanied with radical devaluation of everything which is not agreeable with chosen ideals. Unlike utopian spaces social reality is not created according to a framework of pure reason. Those, who try to construct it on purpose, as if from the scratch, are unlikely to entertain full knowledge about constructed object as well as the consequences of embodied ideals. According to a critical rationalist K. Popper, it is analytical reason, which can restrict the play of imagination fraught with dictatorship of big goals, and be a basis for "piecemeal engineering" [3. P. 64-70].

Construction of social reality does not amount to only purposeful projects directed to the future of different scope and content. Social phenomenologists find it in a sphere which apparently lacks both social imagination and innovative intellectual activities. That is in the sphere of daily routine where everybody turns out to be contributors to creation of social reality in its familiar and unproblematic form.

\section{Institutional order and memory transformations}

The concept of social construction, suggested by P. Berger and Th. Luckmann in 1966 [4] and used intensively since 1980 by different authors [1. P. 4], has nothing to do with individual or collective rational planning. Using ideas from sociology of knowledge as well as social phenomenology, the pioneers of this approach empha- 
sized the role of common beliefs and unaware mental operations within daily routine in maintaining institutional organization. According to their views social order is primarily rooted in mental constructs people use while speaking, playing social roles, following one's obligations, assessing their environment, etc., in short, treating the arrangements of their social world as real and relevant. In this sense the object of construction is not exactly material culture and institutional norms, but general definitions of reality and common stock of knowledge which delineate what is real and what is not. The question is not about producing artifacts or political reforms, but about collective creation of a meaningful picture of the social, shared by the majority and supported by commonly held beliefs in its significance and plausibility.

Drawing a great deal to ideas of A. Schutz, who phenomenologically described mental resources people exploit to make their coexistence with others possible [5], P. Berger and Th. Luckmann pay attention to collective and individual memory transformations which lead to the general recognition that existing regimes of life are necessary and "natural". Thus the social constructionism explores how habitual, stable forms of social being take shape through several generations and individual biography. The most interesting thing here is the transition from anthropological "openness" to social organization, from subjective choice made at one's own risk to common patterns of behaviour, from conventional (even playful) framework to compulsory institutional forms.

J.L. Borges' novel "Lottery in Babylon" written in 1941, anticipates the idea a great deal [6]. As time goes by, the lottery undergoes a radical change from a mere game designed for lower classes to the universal way of directing individual lives. Lottery tickets (favorable together with unfavorable ones) gradually start to gain power over all aspects of social life. Unlike the first generations of players who had choice not to enter the game, the further generations entirely submit their existence to lottery instructions. After a while even organizers forget about the playful and arbitrary character of the game and resort to the help of astrologers and spies for shaping the lots (adapting the tickets to the reality which seems totally independent from their own decisions). In the end the lottery becomes the only reality people reckon with.

According to social constructionist approach, "natural necessity" of social order emerges historically out of human inclination for well-ordered activity, but at the same time for clear-cut picture of social being with its standard invariables: "The institution posits that actions of type $\mathrm{X}$ will be performed by actors of type X. For example, the institution of the law posits that heads shall be chopped off in specific ways under specific circumstances, and that specific types of individuals shall do the chopping (executioners, say, or members of an impure caste, or virgins under a certain age, or those who have been designated by an oracle)" [4. S. 92]. The linguistic constructs here are not just arbitrary conventions, but part and parcel of "institutional facts" [7. P. 93 - 104] that can not be renamed for the sake of a game and enable people to behave rationally in the relatively coherent structure of the world.

Though the idea of chance and multitude initial possibilities lurks behind the concept of social construction, the main emphasis is made on forward movement from exploratory actions to standard and predictable ones: "While in theory there may be a hundred ways to go about the project of building a canoe out of matchsticks", only 
the one is left as habitual and necessary [4. S. 90]. In this sense daily life trims off alternatives, but provides people with relative stability in space and time as a basis for their projects and individual imagination.

In the society of lottery the apparent stability of social structure (roles, functions, regularity of drawing) is a simulacrum of order which produces effects of social life, infinitely combining social elements (a certain inflation of diversity which outruns the natural course of events). It is the world where anything goes and may happen, except human development. People are like puppets under the distributive power of casual prescriptions, which are as compulsory and inevitable as natural laws. Actually it is a world of nomads who have to forget any roots and attachments, combining heavy gamblers' indifference with appearance of social actors. They have no time to develop either basic competences to understand the others, or critical skills to go beyond the given reality. General gambling rejects habitual activity and daily life. Human existence looks like a dotted line of flights and falls, which individuals live through in order to pass time till the next draw (if the consequences of the previous draw do not lead to a lethal outcome).

However the two models of society are similar in widespread disposition to get accustomed to the "circumstances", intentions to put up with "the objective necessity" of existing order. In Babylon lottery the most people take a game as a legitimate authority. Within constructionist approach the vast majority fail to bear in mind the human (historical) origins of existing frameworks and definitions of reality. Successful social construction may result in invisible human alienation when people regard normative reality as natural, unchangeable and the only one available to them (P. Berger and Th. Luckmann call it "reification"). Being in the state of reification a person takes a somewhat narrow and deterministic view on one's life ("I have no choice in the matter, I have to act this way because of my position' - as husband, father, general, archbishop, chairman of the board, gangster or hangman, as the case may be" [4. S. 149]). In its extremity, social construction may result in its opposite (absolute intellectual passivity), when there is nothing to imagine and nowhere to transcend.

Nevertheless the situation of total reification is possible in fictional society, like Babylon lottery, as people take no part in their destinies. In Babylon lottery humans regularly reproduce the same situation of drawing, having no choice against innumerable chances. In utopian space humans regularly make reasonable choice invariably followed by reasonable consequences, having no chance to deviate from the right way of life (the author's plot). In daily life a total reification is a theoretical abstraction, since there are various extents of alienation which depend on personal development and circumstances. As far as daily life is concerned, it is a base for human diverse activities, though human understanding that provides it is not guaranteed automatically and is a product of the continuous social construction as well.

\section{Meaningful world and existential experience}

As P. Berger puts it: "The 'stuff' out of which society and all its formations are made is human meanings" [8. P. 18], in other words, society is made of definite, understandable and human-oriented descriptions which have the status of real and adequate. 
At the level of ordinary life there is no problem of meaning as people use "typifications" (A. Schutz), expressed in familiar terms of natural language, that classified the data, translating unknown or potentially troubling events into ordinary ones, and grant cognitive composure to the most of social actors. Typificatory schemes together with an inclination to refrain from doubts ("the natural attitude of daily life") do not let hypothetical thought interfere into day-to-day communications. B. Russel told about the same phenomena earlier, but in another context: "When we see what looks like our best friend approaching us, we shall have no reason to suppose that his body is not inhabited by the mind of our worst enemy or of some total stranger" [9]. As for social phenomenologists, it is not only inductive reasoning they refer to, but common habits of thought, "cognitive patterns" [10], "axioms" of practical consciousness" [11], which make people produce and reproduce a picture of the stable world, understandable and mutually understandable fields of experience.

According to A. Schutz, "the basic structure of the world as I know it, and therewith the type and style of my experiencing it and of my acting within it, will remain unchanged - unchanged, that is, until further notice" of the reverse [5. P. 384]. Yet in daily reality notice of the reverse is likely to be embedded in pre-existing typifications and theories which help people avoid marginal situations, when habitual structures of the world are not evident any more. In daily life, as social phenomenologists describe it, people usually trust the ontological structure of the world, which is open for their projects under certain circumstances, lets them explain everything on the ground of constant links between events.

Explanations like these are not available for Babylons gamblers, who are accustomed to permanent changes and changeable others without any reasonable cause. Positions and dispositions of friends and enemies, gentlemen and crimes, those who should judge and be blamed are transitory and inconsistent, dependent on the drawing. The sociality in its proper sense fades away, since a social action presupposes understanding of the others and oneself as purposeful actors dealing with comparatively common facts and problems. The lottery keeps everybody in a state of ignorance, autonomy, lost in guesses and apprehension, when one is linked with other people not directly through common knowledge, but indirectly through specialized instructions from tickets caught by chance and altered next time: "Let us imagine a first drawing, which decrees the death of a man. For its fulfillment one proceeds to another drawing, which proposes (let us say) nine possible executors. Of these executors, four can initiate a third drawing which will tell the name of the executioner, two can re-place the adverse order with a fortunate one (finding a treasure, let us say), another will intensify the death penalty (that is, will make it in-famous or enrich it with tortures), others can refuse to fulfill it" [6. P. 206].

However even in Babylon lottery there is some theoretical constructions that smooth over the feeling of absurdity and atomization. Chance is postulated to be a supreme cosmic principle that turns even the most impossible lots into possible and important ones. One of the sacred texts of this game says that "the lottery is an interpolation of chance in the order of the world and that to accept errors is not to contradict chance: it is to corroborate it ... This declaration pacified the public's restlessness" [6. P. 205]. 
This meta-theory is a superstructure casted upon everyday instability to inscribe it into a broad picture of the world, where nobody under any circumstances can make any important decisions. The sacred meaning of chance is the opposite to the sacred meaning of God in "symbolic universes" of traditional religions. P. Berger and Th. Luckmann write about their strong legitimating and explanatory power which integrates any aspect of individual and social change into a system of morally justified and psychologically convenient meanings. Actually symbolic universe is a masterpiece of human construction that has an absolute "sheltering quality" [8. P. 32], as it protects people from the gaps of meanings and from the feeling of ultimate abandonment in the face of infinity.

Anyway no construct, including a symbolic universe, is ever resistant to distrust and mental destruction and so needs other legitimating constructs to survive. P. Berger and Th. Luckmann speak about "the ongoing necessity of keeping chaos at bay. All social reality is precarious. All societies are constructions in the face of chaos" [4. S. 169]. Existence of this edged-with-chaos reality is dependent on common interpretational schemes people use in their everyday life. Thus phenomenological description of "the fabric of meanings" (which produces understandable areas of the world, suitable for social living) opposes existentialist intention to liberate human minds from metatheories as well as from skin-deep generalizations that make a usual and coherent picture of reality people deal with. For social phenomenology the routine with its quickly grasped meanings is a foundation of coexistence with others. For existential authors it is a cause of human alienation. "General ideas are more flattering" [12. S. 102], — as one of Sartre's characters puts it. Simultaneously, intending to cognize the world without any go-between agents (social stock of knowledge), the same character finds himself deprived of all social links: "I am alone in this white, garden-rimmed street. Alone and free. But this freedom is rather like death" [12. S. 225].

Social construction pursues cognitive security with others, while existential experience of border situations leaves a person alone with unfamiliar world not interpreted and humanized through commonly accepted constructs of thought. Societies create certain buffers from critical (border) situations, for example, including them in traditional ritual practice ${ }^{2}$. Fictional society of lottery eliminates border situations by multiplying them, making people indifferent to life and death, chance and necessity, any border at all. Their imagination isn't challenged by any necessity. Meanwhile existential experience in proper sense is an individual revolt against common knowledge used automatically by the majority of people. It encourages an individual to do without any certain grounds and recipes, in ultimate awareness of his/her own responsibility for using this or that kind of knowledge in concrete situations. During existential expe-

${ }^{2}$ Even in the rites of passage [13] which represent how individual enters adultery and dies out for the world of childhood, he experiences a border situation foreseen by tradition and mythological universe. Instead of existential experience of loneliness an individual follows a social stock of knowledge, "dies" as everybody else at his age; it is not an individual choice or discovery, but necessity to keep balance, endure pain tests and separation from familiar milieu in order to become a full member of society. The initiated get new knowledge (open to everybody since a certain age) which is in turn precarious against absurdity as well as a routine of daily life. 
rience individuals cease to be knowledge-users (as in daily life), but become knowledgeexaminers and constructers, starting from the beginning, in the world free from unarticulated meanings. To reach meanings for them is a life-and-death task, they should fulfill on their own.

A. Schutz, Th. Luckmann, P. Berger study reality as a common system of meanings people are interested in, as a base for any individual projects, including ones that transcend existing bounds. Instead of solving the problem of ultimate reality or authenticity of experience, social phenomenologists analyze particularities of knowledge and attitudes which enable people to live, work, communicate with others and feel themselves humans, against relatively understandable background.

\section{A phenomenological beholder of social construction}

An observer of the constructed world should entertain more knowledge about it than actors, who participate in social construction without realizing this fact [11. P. 181]. The position of an observer is not the same as the position of a demiurge. It is closer to existential experience of "starting from the beginnings", but arises from phenomenological procedure of bracketing existing ideas about reality (phenomenological reduction). In this sense an observer sees through stable established forms of social being, overcoming natural or theoretical attitude towards the world. He/she tends to "dismantle" socially recognized reality, mentally return to the situations (sometimes hypothetical ones) which once were open to human imagination, invention and freedom of choice.

Liberated from invisible reifications of daily life, phenomenological observer differs from his/her counterpart in fictional society of Babylon. In the world where everything is dependent on lottery, a position of a narrator (a beholder), who is leaving the city and brooding about historical sources and factors of the game, is ambiguous one, as it might be a result of another lot. Lottery is total and inescapable as a fate, and might manage even beholder's attitude (just for a change).

Being liberated from reification, a phenomenological beholder does not mean to be distanced from simple meanings of daily life. He/she explores reality which is perceived, classified and understood by social actors, men in the street, and simultaneously tries to detect the "rules for "what counts as what" [14. P. 268] that underlie this ordinary understanding. The position of phenomenological beholder resembles one of a social anthropologist who describes symbolic spaces of social world both as an expert and as a participant in certain cultural environment. He/she is neither "a stranger" (since he/she comprehends what is going on, shares existing norms and meanings), nor a man in the street (since he/she beholds social phenomena within a broader context of meanings), but a person who understands more than others as understanding of others is one of his/her key competences.

Evidently a phenomenological beholder reveals a universal principle of shaping a living space. Despite the differences in traditions, habits, outlooks, all of them are derived from a general human need in common reality and knowledge, capable of 
protecting people from chaotic indefiniteness. According to J.-P. Sartre, universal situation man-in-the-world is the following: everyone is present in the world, at work, with other people and everyone is mortal. Social construction paradigm adds another feature to this universality: everyone is a heir to and a successor of social construction processes, everyone is longing for understanding and mutual understanding, and uses a number of conventions elaborated for it. Moreover learning to handle one's world in accustomed frames of communication, ready-made practical recipes and definitions is a basic precondition for learning to handle other cultural lifeworlds, as learning one's own language is a precondition for learning the others.

At first blush phenomenological approach is not critical towards society, since construction is not similar to fabrication, but stands for the processes necessary for social existence and development. Social criticism arises when a beholder views a substitution of meanings, for example, within "false consciousness" under the influence of ideology, gender [15] or ethnic stereotypes [16] or misrepresentation of the real in mass media space [17]. Nevertheless a social phenomenologist does have a critical intention directed primarily against poor understanding of daily life with its cognitive complexity. Because of this complexity the routine can not be drastically changed to please the individual sense of beauty, reason, self-interest or zest for adventure.

The concept of social constructionism illustrates an idea that social reality is not a mechanically compiled assembly where one can change or dismiss structural parts as one likes, but primarily a continuum of interactions supported by interlinked mental processes, responsible for human identification and sense of belonging. Any interfering into these processes, can break a personal and social system of basic meanings, patterns of thought and behaviour. The opposite side of social construction is anomy, a state of being at a loss, "worldless" [8. P. 31], without any significant orientations. In a state of anomy a person can neither join the meaningful definiteness of daily interactions, nor create his/her own worlds of meaning (playful, utopian, subcultural, imaginary etc). In marginal situations (revolutions, wars, totalitarian regimes) the whole society comes to anomy, without any "socially established nomos" and has to endure (not to be accustomed to) instability, which turns reality into a nightmare as in "Babylon lottery".

Against this background, everyday reality without any ontological shake-up is an achievement of collective activities, which at the same time resembles an utopian island among social distubances ${ }^{3}$. But instead of utopian longing for something beyond the bounds of daily life, phenomenological description is imbued with a desire to find and preserve sheltering reality of "lifeworld" where humans feel at home, with understandable grounds and horizons, without suspicious and changeable others. A beholder neither criticizes the standards of day-to-day life (as existential critics do), nor takes a skeptically detached view on given sociality. He/she describes the complex and inventive ways of "world-building" [8. P. 13] in history and individual biography, detects (and is loyal to) the cognitive style that underpins the basics of sociality.

3 As N.M. Smirnova puts it, in a transitory society without stable day-to-day reality, taken for granted patterns of understanding are "fragmented and "instantaneous" [10. S. 120]. 


\section{Conclusion}

Being a source and stronghold of all dreams and imaginary spaces, the reality of daily life takes shape due to a necessary reduction of individual imagination and inventive sorties beyond the common practices ("epoche of natural attitude" (A. Schutz)). According to phenomenologists, social construction implies constant recognition and collective maintenance of common knowledge and subjective certainty in stable structures of the social world shared with others. A phenomenologist's point of view resembles a position of wise deliberate person who appreciate an individual imagination, eagerness to transcend the bounds of daily routine, but also penetrates into the importance of daily existence, its meaningful stratum, cognitive coherence and disposition to interact with others. This existence, though connected with repetitions and standard perceptions, is not a guaranteed entity, but, like any artifact, requires attention and thoughtful care from those who become dissatisfied with it.

Simultaneously a phenomenological position represents a way of transcending the ordinary definiteness of daily life. Unlike utopian pictures that represent an elegantly furnished social models of reasonable life (without exceptions) or Borges' model of gambling society that stands for a simulacrum of social life (switching from rationally motivated actions to irrational ones), social phenomenologists describes the relatively stable continuum of lifeworld, with understandable others as it is perceived in natural attitude. But this world of natural attitude is seen as emerging out of other plausible alternatives and unaware cognitive steps, the actors do not think of. Stepping behind the established form of human existence, a social constructionist does not suggest another way of life, but rather another look at familiar sphere of existence, where by definition, there is nothing new or important.

It does not mean that fictional models of societies do not contribute to understanding of ordinary existence. On the contrary they create distance towards the routine and play through other possibilities of being. Though they do not pretend to correspond to reality, but they do correspond to human searching activities and aesthetic pleasure from the possibility of multiple interpretations (to follow I. Kant's idea). Thus the society of Babylon may be a metaphor of human life in general with its drastic twists, or be close to unconstructed distribution of positions during the primarily socialization ${ }^{4}$. It may also imply the postmodern insight into the power of language games, which trap and submit human minds enforcing them to follow any linguistic combinations ${ }^{5}$.

As far as social phenomenology is concerned, it does not play with everyday life, but rather emphasizes its invisible complexity and significance, connected with the

${ }^{4}$ It is the primary socialization that authors describe very closely to Lottery in Babylon: "Primary socialization thus accomplishes what (in hindsight, of course) may be seen as the most important confidence trick that society plays on the individual - to make appear as necessity what is in fact a bundle of contingencies" [4. S. 220].

5 As far as J.L. Borges is concerned, he "introduces the cancellation of the traditional distinction between fiction and reality" [18. P. 292]. 
processes of ordinary interpretations and common longing to understand and orient oneself adequately in the space one inhabits. At the same time social constructionist view, with its close attention to growth and transformations of meanings, including those in marginal situations, represents the natural intention of philosophical mind to touch the reality in its flow, without closed horizons or systems constructed once and for ever.

Funding and Acknowledgement of Sources. The article was prepared with the support of the RUDN University in the framework of the theme No. 100114-0-000.

\section{References}

[1] Elder-Vass D. The Reality of Social Construction. Cambridge University Press; 2012. 284 p.

[2] Colombo A. The New Sense of Utopia: The Construction of a Society Based on Justice. Utopian Studies. 2000;11(2):181-197. URL: https://www.jstor.org/stable/20718181 (Accessed 02.07.2019).

[3] Popper KL. The Poverty of Historicism. Boston: The Beakon Press; 1957. 166 p.

[4] Berger PL, Luckmann Th. Social Construction of Reality. A Treatise in the Sociology of Knowledge. Moscow: "Medium"; 1995. 323 s. (In Russ.).

[5] Schutz A. The meaningful structure of the social world. Moscow: Institut Fonda "Obschestvennoe mnenie", 2003. 336 s. (In Russ.).

[6] Borges JL. Lottery in Babylon. Prairie Schooner. 1959;33(3):203-207. Stable URL: http://www.jstor.org/stable/40625498 (Accessed 05.03.2019).

[7] Searle JR. Making the Social World. Oxford: Oxford University Press; 2010. 208 p.

[8] Berger PL. The Social Reality of Religion. Harmondsworth: Penguin Books; 1973. 235 p.

[9] Russel B. The Problems of Philosophy. Oxford University Press, 1971. URL: http://www.ditext.com/russell/russell.html (Accessed 01.12.2018).

[10] Smirnova NM. Phenomenology of the Social World in the Context of Contemporary Cognitive Practices. Epistemology and philosophy of science. 2005;3(1):96-120. (In Russ.)

[11] Podvoyskiy D. The World of Everyday Life and the "Axioms" of Practical Consciousness: Social Theoretical Prolegomena. Epistemology and philosophy of science. 2016;49(3):178197. (In Russ.)

[12] Sartre JP. Nausea. Moscow, St Petersburg: Terra, Azbuka; 1997. (In Russ.)

[13] Gennep A. van. The Rites of Passage. Moscow: Vostochnaya literature; 1999. 198 c. (In Russ.)

[14] Gergen KG. The Social Constructionist Movement in Modern Psychology. American Psychologist. 1985;40(3):266-275.

[15] Tagirov PhV. Sex and Identity: From Binary Logic to Humanism of Plurality? RUDN Journal of Philosophy. 2016:(2):30 - 42. (In Russ.).

[16] Chistyakova OV. Media Myth Influence on "Other" Culture Formation in Russian Society (In the Context of External Migration). Scientific Almanac of Black Sea Region Countries). 2015; (1):59-64.

[17] Gampson WA, Croteau D, Hoynes W, Sasson Th. Media Images and the Social Construction of Reality. Annual Review of Sociology. 1992;18:373-393.

[18] De Torro F. Borges and the "construction" of reality. Semiotica. 2013;(195):274-304. 


\title{
Конструирование социальной реальности в литературной фантазии и феноменологии повседневности
}

\author{
С.В. Рудановская \\ Российский университет дружбы народов \\ ул. Миклухо-Маклая, 6, Москва, Российская Федерация, 117198
}

\begin{abstract}
Идея сконструированного характера социальной реальности подразумевает значимость человеческого фактора в формировании институциональных норм и культурных образцов, определяющих специфику социального общежития. В статье исследуются особенности социального конструирования в контексте феноменологического подхода А. Шюца, П. Бергера, Т. Лукмана. Данная концепция акцентирует внимание на когнитивном стиле повседневности, который позволяет людям структурировать и понимать мир, разделяемый ими с другими, а также избегать ситуаций потери смысла и аномии. Автор статьи анализирует феномен социального конструирования в отличие от воображаемых построений социального, направленных за пределы существующего порядка вещей. Мир повседневности сравнивается с фантастической реальностью, представленной в произведении Х.Л. Борхеса «Лотерея в Вавилоне». Изображая процесс социального конструирования каким оно может быть, основанное на сходных ментальных процедурах, это произведение демонстрирует эксцессы и бесчеловечный характер данного феномена. В статье также анализируется позиция феноменологического наблюдателя социальной реальности. С одной стороны, наблюдатель дистанцируется от теоретических абстракций, воображаемых конструкций и социально-критической мысли, подрывающей существующий порядок, с другой - трансцендирует реифицированные формы социального бытия и инициирует особую форму критического восприятия действительности.
\end{abstract}

Ключевые слова: социальная феноменология, социальное конструирование, социальный актор, реификация, экзистенциальный опыт, феноменологический наблюдатель, социальное воображение, «Лотерея в Вавилоне»

\section{Список литературы}

[1] Elder-Vass D. The Reality of Social Construction. Cambridge University Press, 2012. 284 p.

[2] Colombo A. The New Sense of Utopia: The Construction of a Society Based on Justice. Utopian Studies. 2000. Vol. 11. No. 2. pp. 181-197. URL: https://www.jstor.org/stable/20718181 (07.02.2019).

[3] Popper K.L. The Poverty of Historicism. Boston: The Beakon Press, 1957. 166 p.

[4] Бергер П.Л., Лукман Т. Социальное конструирование реальности. Трактат по социологии знания. Пер. Е. Руткевич. М.: Медиум, 1995. 323 с.

[5] Шюти А. Смысловая структура повседневного мира: очерки по феноменологической социологии. М.: Институт фонда общественное мнение, 2003. 336 с.

[6] Borges J.L. Lottery in Babylon // Prairie Schooner. 1959. Vol. 33. N. 3. P. 203-207. Stable URL: http://www.jstor.org/stable/40625498 (05.03.2019).

[7] Searle J.R. Making the Social World. Oxford: Oxford University Press, 2010. 208 p.

[8] Berger P.L. The Social Reality of Religion. Harmondsworth: Penguin Books, 1973. 235 p.

[9] Russel B. The Problems of Philosophy. Oxford University Press, 1971. URL: http://www.ditext.com/russell/russell.html (1.12.2018).

[10] Смирнова Н.М. Феноменология социального мира в контексте современных когнитивных практик // Эпистемология и философия науки. 2005. Т. 3. N 1. С. 96-120.

[11] Подвойский Д. Мир повседневности и «аксиомы» практического сознания: социальнотеоретические пролегомены // Эпистемология и философия науки. 2016. Т. 49. № 3. S. 178 - 197. (In Russ.) 
[12] Сартр Ж.-П. Тошнота. М., СПб.: Терра, Азбука, 1997.

[13] Геннеп А. ван Ритуалы перехода. Систематическое изучение обрядов. М: Восточная литература, 1999. $198 \mathrm{c}$.

[14] Gergen K.G. The Social Constructionist Movement in Modern Psychology // American Psychologist. 1985. V. 40. N 3. P. 266-275.

[15] Тагиров Ф.В. Пол и идентичность: от бинарной логики к гуманизму плюральности? // Вестник РУДН. Серия: Философия. 2016. N 2. С. 30-42.

[16] Chistyakova O.V. Media Myth Influence on "Other" Culture Formation in Russian Society (In the Context of External Migration) // Научный альманах стран Причерноморья. 2015. N 1. C. $59-64$.

[17] Gampson W.A., Croteau D., Hoynes W., Sasson Th. Media Images and the Social Construction of Reality // Annual Review of Sociology. 1992, Vol. 18. P. 373-393.

[18] De Torro F. Borges and the "construction" of reality // Semiotica. 2013. N 195. P. 274-304.

\section{История статьи:}

Статья поступила 30.05.2019

Статья принята к публикации 08.07.2019

Для цитирования: Rudanovskaya S.V. Construction of social reality in fiction and phenomenology of everyday life // Вестник Российского университета дружбы народов. Серия: Философия. 2019. T. 23. No 4. C. 521—532. doi: 10.22363/2313-2302-2019-23-4-521-532

\section{Сведения об авторе:}

Рудановская Светлана Валерьевна - кандидат философских наук, доцент кафедры социальной философии факультета гуманитарных и социальных наук Российского университета дружбы народов (e-mail: rudanovska ya_sv@pfur.ru). 